\title{
The freshwater diaptomid copepod fauna (Crustacea: Copepoda: Diaptomidae) of the Western Ghats of Maharashtra with notes on distribution, species richness and ecology
}

\author{
Mihir R. KULKARNI, Kalpana PAI* \\ Centre for Advanced Studies, Dept. of Zoology, Savitribai Phule Pune University (formerly the University of Pune), Pune 411007, \\ Maharashtra, India \\ *Corresponding author: drkalpanapai@gmail.com
}

\begin{abstract}
The diversity of many invertebrate taxa from Western Ghats of Maharashtra remains unknown due to lack of systematic studies. We studied freshwater calanoid copepods from this region, and found eleven species of diaptomid copepods in 180 samples collected from 80 sites in the study area. Most of these are new records for this region. The observed fauna includes Oriental, Gondwanan, Palaearctic and Indian endemic taxa. Locality data for all the observed species, along with notes on some ecological aspects of the sampled sites are provided. Non-parametric estimates of species richness for the region suggested an overall adequacy of sampling effort, and probable missing out of some species from habitats with longer hydroperiod. Hydroperiod, depth, electrical conductivity, altitude, mean annual temperature and latitude largely influenced the distribution of species in the study area. Co-occurrences of species were overall rare but more common in temporary habitats. Assemblages of diaptomid copepods restricted to certain sites were identified. The importance of temporary habitats is discussed in the light of their species richness, faunal composition and the increasing anthropogenic pressures they face.
\end{abstract}

Key words: Western Ghats; Copepoda; distribution; assemblages; temporary habitats.

Received: May 2015. Accepted: September 2015.

\section{INTRODUCTION}

Freshwater copepods are represented by over 2500 species, mostly free-living, but some are also parasitic (Boxshall and Defaye, 2008). The former often dominate the zooplankton communities and play crucial role of both primary and secondary consumers in aquatic ecosystems and also as a major food source for other aquatic predators. The calanoid copepods (Copepoda: Calanoida) are principally represented by the family Diaptomidae in the inland waters of the Oriental biogeographic region (Dussart and Defaye, 2001). Of about 381 species of inland water copepods reported from the Oriental region, 92 of the 96 species of Calanoida are diaptomids. The Oriental region harbours 22 genera of diaptomids, of which 10 genera, represented by 81 species, are endemic to the region (Boxshall and Defaye, 2008).

The Indian Diaptomidae are represented by two subfamilies, namely the Diaptominae and the Paradiaptominae (Dussart and Defaye, 2002). The Diaptominae are the dominant sub-family, represented by 12 genera and over 50 species while the Paradiaptominae are represented in India by a single genus and species (Rayner, 2000). Gur- ney (1907), Sewell (1924), Brehm (1950), Kiefer (1936, 1982) have done pioneering studies on the Indian diaptomid fauna, and others like Reddiah (1964), Rajendran (1971), Abraham (1972) and Flößner (1984) have also contributed to this knowledge. Ranga Reddy has carried out extensive work on the Indian diaptomids describing several new species from the country (Ranga Reddy, 1988, 1994 and references therein; Ranga Reddy, 2013a, 2013b). However, most of the studies on Indian diaptomids have been restricted to the southern parts of the country (Dussart and Defaye, 2002), with some reports from the north-eastern region (Reddiah, 1964; Ranga Reddy, 2013a, 2013b). Recently, Ambedkar (2012) has carried out some work on the Indian Diaptomidae, however, some regions, notably the Western Ghats, have not been studied to date.

Systematic studies on several invertebrate taxa, including diaptomid copepods, are lacking from the Western Ghats, in spite of it being declared a megadiverse region and a biodiversity hotspot (Myers et al., 2000; Mittermeier et al., 2005). There is, at present, a need to undertake studies on important planktonic groups such as copepods in this area, as various areas in the Western 
Ghats are currently under tremendous anthropogenic pressure. Some scattered publications are known from Maharashtra, but these are restricted to faunal inventories of single water bodies (usually reservoirs) (Pandit et al., 2007; Lahane and Jaybhaye 2013; Sehgal et al., 2013) which are far from being comprehensive due to exclusion of other habitat types.

The objectives of this study were: i) to document the diversity of freshwater diaptomids from the Western Ghats of Maharashtra (also known as the Northern Western Ghats and hereafter referred to as NWG); ii) to derive estimates of the actual diaptomid species richness in this region; and iii) to identify the ecological factors influencing the distribution of observed species.

\section{METHODS}

\section{Study area}

The Western Ghats are the edge of a high escarpment, extending over $1600 \mathrm{~km}(\mathrm{~N}-\mathrm{S})$ along the western coast of India. The average elevation of the hills ranges from 600 to $1000 \mathrm{~m}$ asl with elevations of $1000-2000 \mathrm{~m}$ asl occurring in the northernmost and southern regions (Mani, 1974). The states of Maharashtra and Goa are situated in the northern parts of the Ghats, which are part of the Deccan plateau composed predominantly of basaltic rock (although lateritic formations are also observed in certain regions) (Jog et al., 2002). The region receives rainfall during the monsoon season (June-September), followed by a dry period (October-May) (Mani, 1974).

\section{Sampling}

Sampling was carried out in the NWG, a stretch of over $400 \mathrm{~km}$ in length (N-S) lying between 16 and $21^{\circ} \mathrm{N}$ (Fig. 1A). Qualitative samples were collected from 80 sites in the region in the years 2013-14; furthermore, some samples collected previously during 2010-12 were also screened. Different habitat types like temporary pools, ponds, tanks, rock quarries, slow-flowing streams and reservoirs were sampled. To account for possible inter-seasonal and inter-annual differences in copepod assemblages, multiple samples (over seasons) were collected when possible. Samples were collected using both hand-held and tow nets (mesh size 100 and $80 \mu \mathrm{m}$, respectively) from various habitat types and fixed in 4$5 \%$ formalin or absolute ethanol. Geographical co-ordinates and altitude were obtained using a handheld GPS or using GoogleEarth ${ }^{\odot}$. Some physical and chemical parameters $(\mathrm{pH}$, temperature, electrical conductivity) for habitats were measured using a handheld probe. Additionally, features such as type of habitat, depth of water column, presence/absence of vegetation, type of substratum and presence/absence of fish were also noted on field.

\section{Identification}

Specimens were sorted with a stereo microscope and identified following standard procedures and literature (Ranga Reddy, 1988, 1994; Dussart, 1989; Rayner, 1999; Dussart and Defaye, 2001).

\section{Data analyses}

Maps were prepared using DiVA-GIS v 7.5. Environmental variables (Mean annual temperature, Altitude) were extracted from BIOCLIM data (Hijmans et al., 2005; http://www.worldclim.org) using the same software.

Habitats were categorized as having short, moderate and long hydroperiods of 1-5, 5-9 and 9-12 months and assigned to levels 1, 2 and 3 respectively. Species were classified as Rare (R), Average (Av), Common (C) and Widespread (WS) based on their occurrence in $<5 \%, 5$ $15 \%, 15-40 \%$ and $>40 \%$ of sampled sites, respectively.

Species richness was estimated using non-parametric estimators (Chao 2 (bias-corrected), Jackknife 1, Jackknife 2 and Bootstrap) for incidence-based data (Colwell and Coddington 1994) and calculated using EstimateS (v. 9.1) (Colwell, 2013; http://viceroy.eeb.uconn.edu/EstimateS) with 500 randomizations per sample point. Canonical Correspondence Analysis (CCA) was performed in PAST (v 3.0, Hammer et al., 2001) to analyse influence of ecological factors on distribution of species. Hydroperiod, $\mathrm{pH}$, mean annual precipitation, presence of aquatic vegetation, depth, latitude, mean annual temperature, altitude and electrical conductivity were used for the analysis. Habitat type was used as categorical variable. Data for some variables (presence of fish, substratum, were not available for previously collected samples, and hence these variables were not considered for the final analysis. 999 Monte Carlo permutations were performed to test the significance of the analyses.

To quantify the co-occurrence of species, Fager's Index of affinity (IF) (Fager, 1957; Maeda-Martinez et al., 1997; Padhye and Dahanukar, 2015) was calculated as:

$I F=2(n 1+2) /(n 1+n 2)$

where:

$(n 1+2)=$ no. of joint occurrences of species 1 and 2 ;

$n 1=$ no. of occurrences of species 1 ;

$n 2=$ no. of occurrences of species 2 .

The format for denoting the assemblage patterns was adopted from Maeda-Martinez et al., (1997).

\section{RESULTS}

A total of 180 samples were collected from 80 sites in the study area (Fig. 1A), from which eleven species of calanoid copepods belonging to eight genera and two subfamilies were identified. Of these, nine are new records 

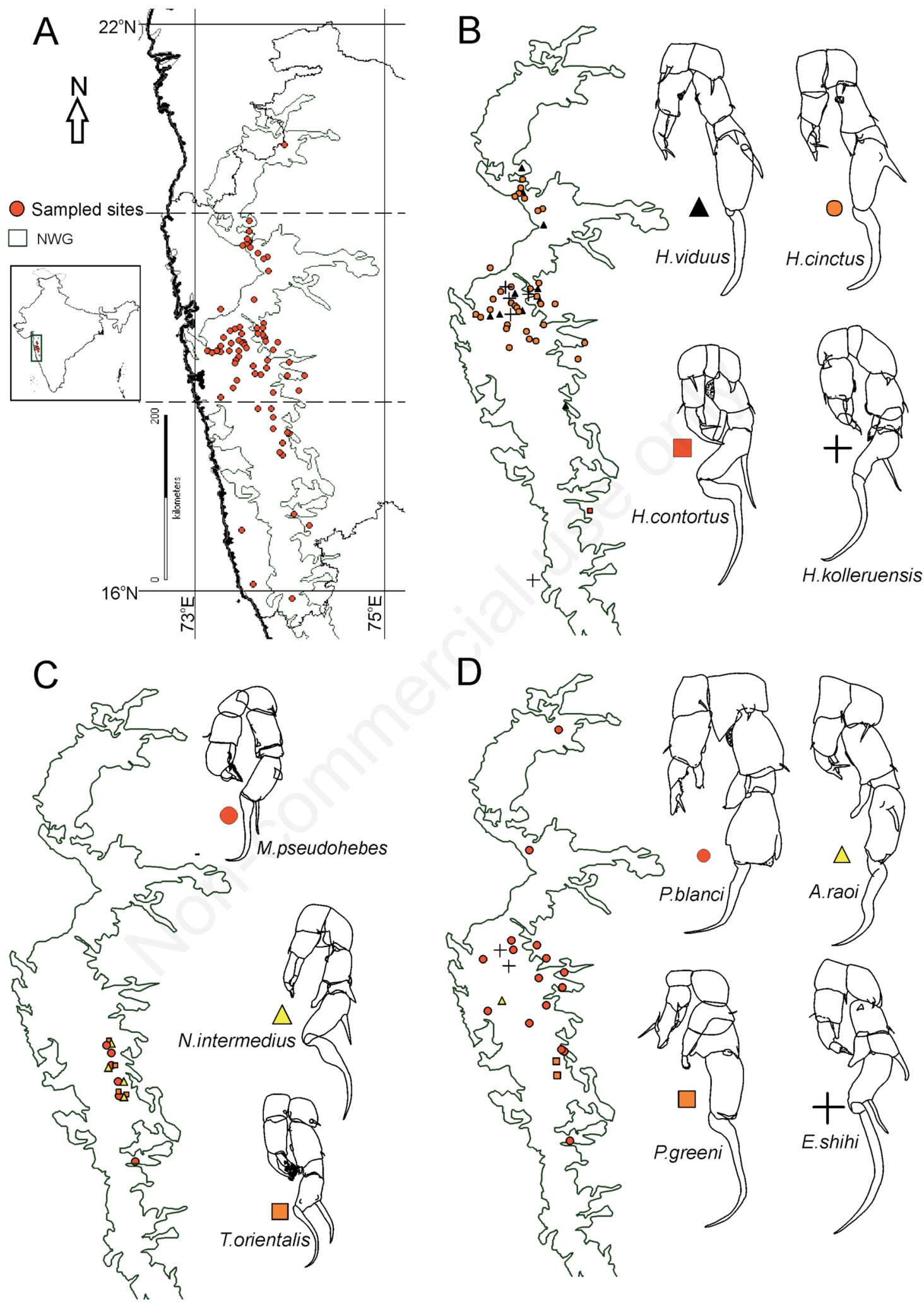

Fig. 1. Map of study area showing (A) sampling sites and distribution of: (B) Heliodiaptomus species; (C) M. pseudohebes, N. intermedius and T. orientalis; (D) P. blanci, A. raoi, P. greeni and E. shihi in the study area along with illustrations of male P5's of the respective species (illustrations not to scale). 
(Tab. 1, indicated by the asterisk) for the Western Ghats of Maharashtra, and also for the whole state of Maharashtra.

\section{Faunistic results}

The observed diaptomid fauna was dominated by the Diaptominae (10 species), while the Paradiaptominae was represented by Paradiaptomus greeni (Gurney, 1906), the sole representative of the sub-family in India (Rayner, 2000). The species of the Diaptominae were observed in various habitat types, and over a wide range of altitudes (25-1300 m asl), while P. greeni was found only in shortlived pools at high altitudes $(>900 \mathrm{~m}$ asl). Short-lived pools at high altitudes harboured other species like Megadiaptomus pseudohebes Ranga Reddy 1988, Tropodiaptomus orientalis (Brady 1886) and Neodiaptomus intermedius Flößner 1984. Eodiaptomus shihi Ranga Reddy 1992, the sole representative of the genus in India, which was earlier thought to be restricted only to central India (Ranga Reddy 1994), was also recorded in this study. Heliodiaptomus was the most species-rich genus among those observed, with four of the five known species from India (Dussart and Defaye, 2002; Ranga Reddy, 1994) being found. Heliodiaptomus cinctus (Gurney 1907) and Phyllodiaptomus blanci (Guerne and Richard 1896) were the most widely distributed species in the region (Fig. 1 B,D), while $M$. pseudohebes, $P$. greeni, E. shihi, N. intermedius, T. orientalis and Allodiaptomus (Reductodiaptomus) raoi Kiefer 1936a showed restricted distribution (Fig. 1 C,D). M. pseudohebes, $N$. intermedius, T. orientalis and P. greeni occurred exclusively in fishless rock pools located at high altitudes (>900 m asl). E. shihi was observed in a large reservoir and, for the first time, in an isolated, rain-fed pond on a hill fort as well. A. raoi was observed in a single sample from a slow-flowing stream at low altitude ( $25 \mathrm{~m}$ asl).

\section{Efficiency of the sampling effort}

The estimates for species richness closely matched our observations for the pooled samples. Estimated Jackknife and Bootstrap indices indicated that one species might have been missed out in the current sampling (Tab. 2). Habitats with moderate hydroperiods showed a higher species richness (both observed and estimated) than those with short or long hydroperiods. For habitats with short hydroperiod, the estimators predicted a missing out of a single species, whereas for habitats with moderate and long hydroperiod, maximum of five and four species respectively were estimated to be missed out. Overall, our samples covered about $90 \%$ of the estimated species richness of the study area. Conversely, $87 \%, 64 \%$ and $63 \%$ coverage of species richness was observed for habitats with short, moderate and long hydroperiod respectively.

\section{Ecological factors affecting species' distribution}

Seventy percent of the observed variance was explained by the first two CCA axes (permutations=999; trace $=1.432 ; \mathrm{P}=0.001$ ). Altitude, mean annual temperature and hydroperiod, were strongly correlated with CCA axis 1 (scores $0.75,-0.73$ and -0.65 , respectively), while latitude, depth and electrical conductivity showed relatively weak correlations (scores $-0.53,-0.51$ and -0.43 , respectively). Mean annual precipitation, $\mathrm{pH}$ and aquatic vegetation showed very weak correlations with axis 1 (scores $0.12,-0.07$ and -0.065 , respectively). Pools harboured the most diaptomid species (7) as compared to ponds (6 species), tanks (5 species), lakes (2 species), reservoirs (4

Tab. 1. Species observed in the study along with their localities of occurrence and relative occurrence.

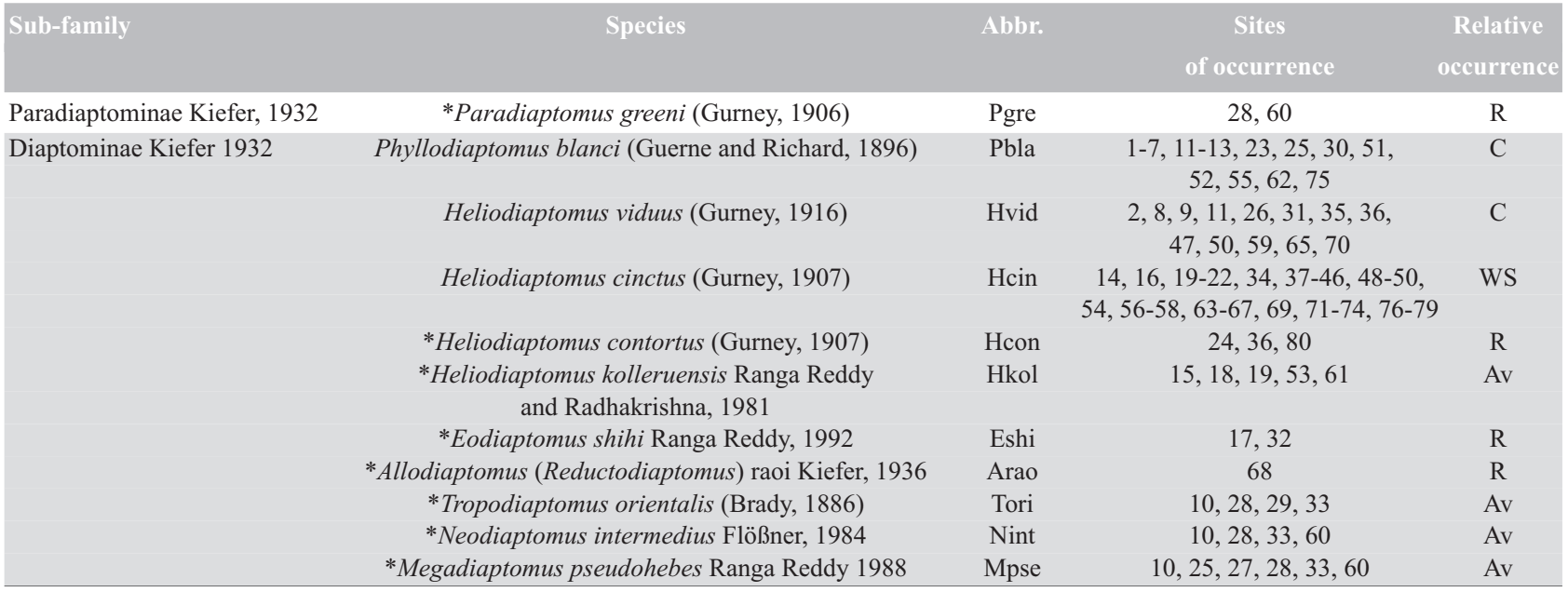

* New record for Maharashtra and NWG; see Supplementary Tab. 1 for sites codes correspondence. 
species) and streams (2 species) (Fig. 2). H. cinctus and $H$. viduus were observed in a variety of habitats, most being relatively deep and having longer hydroperiods. $P$. blanci also occupied a variety of habitats, but was restricted to relatively shallow habitats with short to moderate hydroperiods at higher altitudes. Distribution of four species (M. pseudohebes, $T$. orientalis, $N$. intermedius and $P$. greeni) was negatively correlated to depth and latitude and positively correlated to altitude, reflecting their observed occurrence in shallow, high altitude ( $>900 \mathrm{~m}$ asl) habitats with short hydroperiod located between $17-18^{\circ} \mathrm{N}$ (Fig. 1 A,C,D; Fig. 2).

\section{Species co-occurrence}

Co-occurrences of species were observed in 20 samples $(11 \%$ of the total), of which 18 were habitats with short hydroperiod. Species of Diaptominae and Paradiaptominae co-occurred very rarely $(\mathrm{IF}=0.13)$, and co-occur- rence of congeneric species was also rare and restricted to reservoirs (only in 3 samples out of the 180 collected). $N$. intermedius showed the highest co-occurrences with three other species, the most being with M. pseudohebes. $H$.cinctus co-occurred with two other congeners, however, H. viduus did not show such co-occurrences (Tab. 3). E. shihi and $A$. raoi did not co-occur with any other species. Most of the sampled sites harboured single species and occurrences of multiple species were restricted to sites located at higher altitudes (Fig. 3). Lateritic outcrops were observed to exclusively harbour assemblages of $M$. pseudohebes or $P$. greeni with $N$. intermedius and T. orientalis; however no co-occurrences of $M$. pseudohebes and P. greeni were observed (Tab. 3).

\section{DISCUSSION}

This present report of 11 species of diaptomid copepods from the NWG, constitutes about $22 \%$ of the known

Tab. 2. Species richness estimates for the study area based on empirical observations and non-parametric methods.

\begin{tabular}{|c|c|c|c|c|c|c|}
\hline \multirow[t]{2}{*}{ Habitats } & \multirow[t]{2}{*}{ No. of samples observed } & \multicolumn{5}{|c|}{ Species richness } \\
\hline & & Empirical & Chao2 & Jack1 & Jack2 & Bootstrap \\
\hline All & 180 & 11 & 11 & $12(11.99)$ & 12 & $12(11.55)$ \\
\hline Short hydroperiod & 65 & 7 & $7(7.12)$ & $8(7.85)$ & $8(7.99)$ & $7(7.44)$ \\
\hline Moderate hydroperiod & 59 & 9 & $10(10.47)$ & $12(11.95)$ & $14(13.9)$ & $10(10.28)$ \\
\hline Long hydroperiod & 56 & 7 & $8(7.98)$ & $9(8.96)$ & $11(10.89)$ & $8(7.81)$ \\
\hline
\end{tabular}

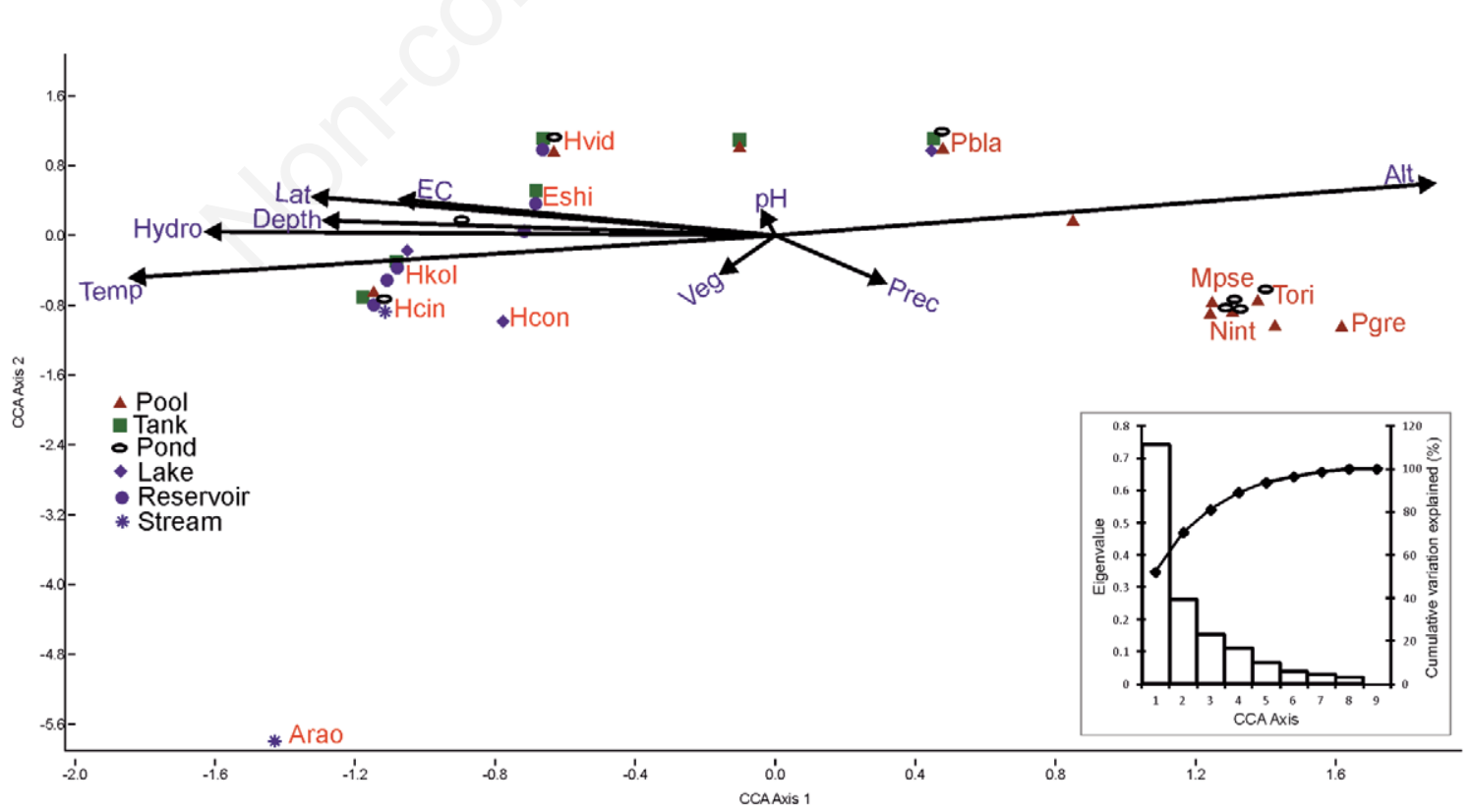

Fig. 2. CCA plot showing relationships between studied environmental variables and observed species for all studied sites. Scree plot is shown in the inset. Species codes as given in Tab. 1. EC, electrical conductivity; Lat, latitude; Hydro, hydroperiod; Temp, mean annual air temperature; Veg, presence of aquatic vegetation; Prec, mean annual precipitation; Alt, altitude. 
diaptomid fauna of India ( $\sim 50$ species; Ranga Reddy, 2013a) and about $45 \%$ of the known fauna of peninsular India ( $\sim 25$ species; Ranga Reddy, 2013a). This provides new distributional records for most species, some of which (e.g., E. shihi, H. kolleruensis, N. intermedius and M. pseudohebes) are known to be rare and/or were previously thought to be restricted only to certain areas of India, thus highlighting the paucity of comprehensive survey data from many areas of the country. There are reports on the rotifers and cladocerans from north-east India (Sharma and Sharma, 2007, 2014 and references therein), however, only few reports of freshwater diaptomids are available (Reddiah, 1964; Ranga Reddy, 2013a, 2013b). On the other hand, many species have been reported/described from the southern and eastern areas of the country (Ranga Reddy, 1994; Dussart and Defaye, 2002). Due to this overall Data Deficiency for most species, their IUCN conservation status must be interpreted with caution.

Lack of detailed distributional data in the available literature makes comparative analyses difficult. Additionally, obscure publications can cause incorrect and often inflated distributional records, especially of understudied groups such as zooplankton, primarily due to the lack of adherence to standard identification methods (see discussion in Padhye and Dumont, 2015). A brief survey of literature published from Maharashtra alone (Pandit et al., 2007; Kale, 2013; Lahane and Jaybhaye, 2013; Sehgal et al., 2013; Meshram, 2014) revealed reports of species which are common (e.g., P. blanci, H. viduus), or conversely, non-existent (e.g., Diaptomus edax, Diaptomus minutus) or have no known distribution in India (i.e., Eodiaptomus japonicus). Hence, we did not consider any of these reports as valid distributional records.

The diaptomid fauna of the NWG, as is currently known from our study, comprises eleven species. Nonparametric species richness estimates suggested an ade- quate sampling effort covering about $90 \%$ of the estimated richness, although only $63 \%$ of estimated species richness for habitats with long hydroperiod was covered. These estimates might be a consequence of the relatively small sample sizes (as is apparent from the estimates for all samples and those for the different hydroperiod classes; Tab. 2), but nevertheless are useful as these are the first for the region. Alternatively, the non-representative sampling of large habitats (like lakes, reservoirs) often due to logistic constraints and under-representation of some habitat types such as slow flowing rivers and streams in our samples can also influence the observed species richness. A more rigorous sampling of large habitats with moderate-to-long hydroperiod might yield additional species, as presence of multiple species from such

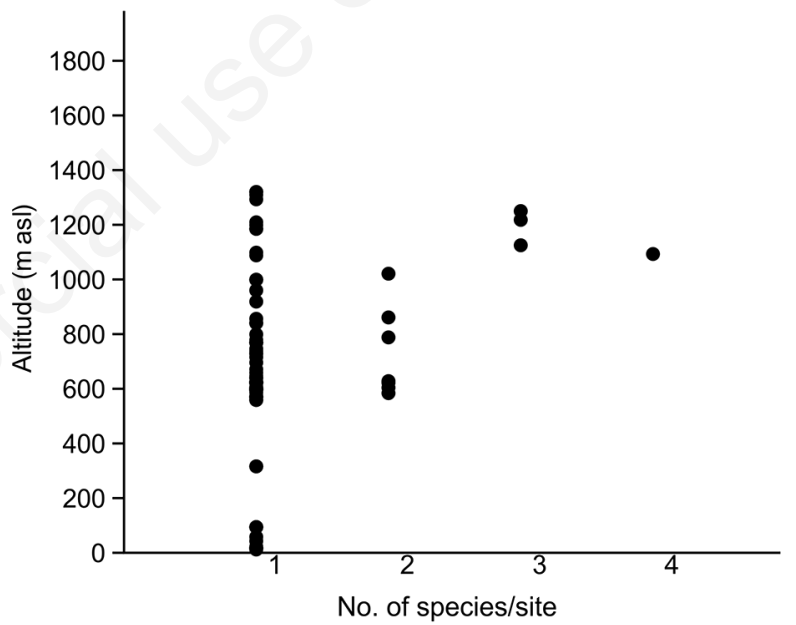

Fig. 3. Altitudinal distribution of sampled sites showing trends in species richness.

Tab. 3. Matrix for co-occurrences of the observed species. Lower part shows number of samples where the species co-occurred. Upper part shows Fager's Affinity Index (X100).

\begin{tabular}{|c|c|c|c|c|c|c|c|c|c|c|c|}
\hline & Mpse & Tori & Nint & Pgre & Pbla & Hvid & Hein & Hkol & Hcon & Eshi & Arao \\
\hline Mpse & & 11.1 & 45.4 & - & 3.2 & - & - & - & - & - & - \\
\hline Tori & 2 & & 25 & - & - & - & - & - & - & - & - \\
\hline Nint & 5 & 4 & & 13.3 & - & - & - & - & - & - & - \\
\hline Pgre & 0 & 0 & 1 & & - & - & - & - & - & - & - \\
\hline Pbla & 1 & 0 & 0 & 0 & & 10 & - & - & - & - & - \\
\hline Hvid & 0 & 0 & 0 & 0 & 4 & & 2.5 & - & 5.8 & - & - \\
\hline Hcin & 0 & 0 & 0 & 0 & 0 & 1 & & 3.4 & - & - & - \\
\hline Hkol & 0 & 0 & 0 & 0 & 0 & 0 & 1 & & - & - & - \\
\hline Hcon & 0 & 0 & 0 & 0 & 0 & 1 & 0 & 0 & & - & - \\
\hline Eshi & 0 & 0 & 0 & 0 & 0 & 0 & 0 & 0 & 0 & & - \\
\hline Arao & 0 & 0 & 0 & 0 & 0 & 0 & 0 & 0 & 0 & 0 & \\
\hline
\end{tabular}

Species abbreviations as per Tab. 1 . 
habitats has been reported earlier (Ranga Reddy and Radhakrishna, 1984; Ranga Reddy, 2013a). Use of molecular tools for taxonomy might reveal cryptic diversity, especially in case of widespread species like P. blanci, (see Dussart and Defaye, 2002; Marrone et al., 2014), as reported for other taxa (Korn et al., 2013 - Notostraca; Marrone et al., 2010, 2013 - West Palaearctic Diaptomidae; Schwentner et al., 2013 - Cyclestherida). These findings in relatively large and well-studied Crustacea highlight the potential of discovery of unknown diversity in other groups as well.

Among the ecological factors affecting distribution of diaptomid species, altitude, depth and electrical conductivity had a significant effect, as noted in other studies as well (Jersabek et al., 2001; Frisch et al., 2006; Marrone et al., 2006). Influence of hydroperiod on distribution of copepods has also been noted by Tavernini et al. (2003), Frisch et al. (2006) and Alfonso and Belmonte (2011). Hydroperiod can affect distribution of species depending on their ability to produce resting eggs or by modulating predation by fish, which are usually absent from short lived habitats. Although we did not include fish presence as a variable in our analyses, predation is known to affect distribution of species, especially calanoid copepods (Jersabek et al., 2001).Vegetation has been reported to affect distribution of copepods (Frisch et al., 2006); however we did not find a strong influence of vegetation on distribution of the observed species. Perhaps, significant effects might be observed if factors like phytoplankton composition and densities are considered. The influence of latitude on species distribution is apparent as some species (i.e., $M$. pseudohebes, $N$. intermedius, $T$. orientalis, $P$. greeni) occurred only on high lateritic outcrops situated typically between $16-18^{\circ} \mathrm{N}$ (Mani, 1974), contributing to the distinct fauna of temporary pools restricted to these sites.

Habitat permanence is known to affect crustacean species richness (Frisch et al., 2006), with permanent habitats usually having higher species richness (Eitam et al., 2004 -Cladocera and Ostracoda); however, this might vary depending on the taxon studied (see discussion in Eitam et al., 2004; Frisch et al., 2006). Higher species richness of copepods in habitats with moderate hydroperiods has been reported by Frisch et al. (2006), and this was observed in our study as well, although their definition of moderate (3-5 months) was shorter than ours. Interestingly both co-occurrences and species richness were higher in smaller pools and ponds than in larger reservoirs. Alfonso and Belmonte (2011) observed a similar pattern in Apulian inland waters, where most diaptomid species occurred in temporary habitats. Species' co-occurrence can be influenced by factors like food availability, predation, resource partitioning between the co-occurring species and temporal dynamics of the habitat (King et al., 1996). Thus, the co-occurrence of con- generic species can be expected to be a rarity, as we observed (Tab. 3). The co-occurrence of species of the Paradiaptominae and Diaptominae has also been reported to be rare, as observed in our study area, possibly due to the competitive superiority of the Diaptominae (Rayner, 2000). Largely fluctuating ecological conditions which characterize smaller, short lived habitats might influence the assemblage structures, and the temporal dynamics of assemblages we observed need further exploration. Alternative explanations for our observations might be the possible non-representativeness of our samplings in reservoirs due to logistic constraints (as compared to the pools which could be thoroughly sampled) and the absence of fish predation in most temporary habitats, both of which can affect species richness and co-occurrences.

Four genera showing a typical Oriental distribution (Heliodiaptomus, Neodiaptomus, Eodiaptomus and Allodiaptomus), two genera showing a Gondwanan distribution (Paradiaptomus and Tropodiaptomus), one genus distributed both in the Palaearctic and Oriental regions (Phyllodiaptomus) and one genus restricted to peninsular India and Sri Lanka (Megadiaptomus) were observed in the NWG. The dominance of Oriental elements in the present day fauna of peninsular India is not surprising, and it has been noted earlier for various taxa such as insects, fish, reptiles (Mani, 1974) and diaptomid copepods as well (Ranga Reddy, 2013a). However, recent/updated faunistic reports on freshwater Diaptomidae are not available from all the countries in the Indian subcontinent and south-east Asia, owing to which comparative analyses of the Diaptomidae fauna, which can be important in understanding the biogeographical evolution of the diversity, cannot be performed.

\section{CONCLUSIONS}

Temporary habitats have been viewed to be good model systems for ecological and evolutionary studies (Brendonck et al., 2010), but till recently they have been quite neglected by researchers (King et al., 1996) especially in Asia (Jocque et al., 2010). Fauna of some temporary pools in the NWG included rare/endemic diaptomid species and species assemblages which were not encountered in other habitats (Tab. 3) in addition to rare ostracods (Shinde et al., 2014), assemblages of large branchiopods and the highly restricted anostracan Streptocephalus sahyadriensis (Padhye and Dahanukar, 2015). Most of our sampled sites, especially some of the lateritic outcrops, occur in areas frequented by tourists, or threatened by the onslaught of urbanization and associated anthropogenic pollution. Habitat loss due to urbanization is known to lead to local extinction of species (Brendonck et al., 2008). Freshwater habitats are particularly vulnerable to these threats (Molur et al., 2011), as loss of habitats and their fauna/flora due to development, pollution 
and resultant eutrophication is reported (Brendonck et al., 2008). Temporary pools, with their short inundation phases, are particularly prone to such destruction (Brendonck et al., 2008; Shinde et al., 2014), and often are invisible to conservation agencies (Marrone et al., 2006) despite harbouring rare and interesting fauna.

In this scenario, the data about the fauna of such seemingly insignificant habitats will prove to be of use for planning and implementing sound conservation action.

\section{ACKNOWLEDGEMENTS}

MRK thanks all his colleagues for their help in collections, and Dr. Y. Ranga Reddy, Dr. Hemant Ghate, Dr. Federico Marrone, Dr. T. Karanovic, Dr. Neelesh Dahanukar and Dr. Sameer Padhye for literature, help and advice. MRK thanks the Council for Scientific and Industrial Research, India (CSIR) for a junior research fellowship. KP is supported by the University of Pune University with Potential for Excellence grant (UoPUPE), Board of College and University Development grant (BCUD), University Grants Commission- Centre for Advanced Studies grant (UGC-CAS) and Department of Science and Technology- Promotion of University Research and Scientific Excellence grant (DST- PURSE), and both authors thank these agencies for funding. The Maharashtra State Biodiversity Board (MSBB) granted a collection permit (MSBB/NOC/778/319/14-15) to KP. Both authors also thank the reviewers for their helpful criticisms.

\section{REFERENCES}

Abraham S, 1972. A redescription of Heliodiaptomus cinctus (Gurney, 1907) and Allodiaptomus mirabilipes Kiefer, 1936 (Copepoda, Calanoida) and their occurrence in Cochin backwaters, India. Crustaceana 22:249-258.

Alfonso G, Belmonte G, 2011. Calanoida (Crustacea Copepoda) from the inland waters of Apulia (south eastern Italy). J. Limnol. 70:57-68.

Ambedkar D, 2012. Morphotaxonomy and biogeography of diaptomid copepods in India with description of four new species of the genus Tropodiaptomus Kiefer 1932 (Crustacea: Calanoida). PhD Thesis, Acharya Nagarjuna University.

Boxshall GA, Defaye D, 2008. Global diversity of copepods (Crustacea: Copepoda) in freshwater. Hydrobiologia 595: 195-207.

Boxshall GA, Defaye D, 2009. World checklist of freshwater Copepoda species. World Accessed on: 16/03/2015. Available from: http://fada.biodiversity.be/group/show/19

Brehm V, 1950. Contributions to the freshwater fauna of India, part I and II. Rec. Indian Mus. 48:1-3 and 9-28.

Brendonck L, Rogers DC, Olesen J, Weeks S, Hoeh WR, 2008. Global diversity of large branchiopods (Crustacea: Branchiopoda) in freshwater. Hydrobiologia 595:167-176.

Brendonck L, Jocque M, Hulsmans A, Vanschoenwinkel B, 2010. Pools 'on the rocks': freshwater rock pools as model system in ecological and evolutionary research. Limnetica 29:25-40.
Colwell RK, Coddington JA, 1994. Estimating terrestrial biodiversity through extrapolation. Philos. T. R. Soc. B 345: 101-118.

Colwell RK, 2013. Estimate S: Statistical estimation of species richness and shared species from samples, ver. 9. Available from: http://purl.oclc.org/estimates

Dumont HJ, Green J, 2005. Eodiaptomus indawgyi n. sp., a pelagic calanoid copepod presumed endemic to ancient Lake Indawgyi, Myanmar. Hydrobiologia 533:41-44.

Dussart BH, 1989. Tropodiaptomus orientalis (Brady, 1886) description d'un neotype. Hydrobiologia 175: 233-236.

Dussart B, Defaye D, 2001. Introduction to the Copepoda. Backhuys, Leiden: 344 pp.

Dussart B, Defaye D, 2002. The World directory of Crustacea: Copepoda of inland waters - Calaniformes. Backhuys, Leiden: $276 \mathrm{pp}$.

Eitam A, Blaustein L, Van Damme K, Dumont HJ, Martens K, 2004. Crustacean species richness in temporary pools: relationships with habitat traits. Hydrobiologia 525:125-130.

Fager EW, 1957. Determination and analysis of recurrent groups. Ecology 38: 86-595

Flößner D, 1984. Neodiaptomus intermedius n. sp. (Calanoida: Copepoda) from South India. Hydrobiologia 108:259-263.

Frisch D, Moreno-Ostos E, Green AJ, 2006. Species richness and distribution of copepods and cladocerans and their relation to hydroperiod and other environmental variables in Doñana, south-west Spain. Hydrobiologia 556:327-340.

Gurney R, 1907. Further notes on Indian freshwater Entomostraca. Rec. Indian Mus. 1:21-33.

Hammer Ø, Harper DAT, Ryan PD, 2001. PAST: Paleontological statistics software package for education and data analysis. Palaeontol. Elec. 4:1-9.

Hijmans R, Cameron SE, Parra JL, Jones PG, Jarvis A, 2005. Very high resolution interpolated climate surfaces for global land areas. Int. J. Clim. 25:1965-1978.

Jersabek CD, Brancelj A, Stoch F, Schabetsberger R, 2001. Distribution and ecology of copepods in mountainous regions of the Eastern Alps. Hydrobiologia 453/454:309-324.

Jocque M, Vanschoenwinkel B, Brendonck L, 2010. Freshwater rock pools: a review of habitat characteristics, faunal diversity and conservation value. Freshwater Biol. 55:1587-1602.

Jog SR, Wakhare A, Chaudhuri S, Unde M, Pardeshi SD, 2002. Maharashtra landscape: A perspective, pp. 19-57. In: J. Diddee, S.R. Jog, V.S. Kale and V.S. Datye (eds.), Geography of Maharashtra. Rawat Publications.

Kale GB, 2013. Zooplankton diversity of Dnyanganga Reservoir near Khamgaon, Maharashtra. Golden Research Thoughts $3: 1-4$.

Kiefer F, 1936. [Weitere neue Ruderfußkrebse (Crustacea:Copepoda) aus Indien].[Article in German]. Zool. Anz. 113:1-6.

Kiefer F, 1982. Comparative studies on morphology, taxonomy and geographical distribution of the species of the genus Tropodiaptomus Kiefer from Asiatic inland waters. Hydrobiologia 93:223-253.

King JL, Simovich MA, Brusca RC, 1996. Species richness, endemism and ecology of crustacean assemblages in northern California vernal pools. Hydrobiologia 328:85-116.

Korn M, Rabet N, Ghate H V, Marrone F, Hundsdoerfer A, 2013. Molecular phylogeny of the Notostraca, Mol. Phylogenet. Evol. 69: 1159-1171. 
Lahane LD, Jayabhaye UM, 2013. Diversity of zooplankton in Pimpaldari tank Dist: Hingoli, Maharashtra, India. Shodh Samiksha aur Mulyankan 4:20-21.

Maeda-Martínez MA, Belk D, Barboza OH, Dumont HJ, 1997. Large branchiopod assemblages common to Mexico and the United States. Hydrobiologia 359:45-62.

Magurran AE, 2004. Measuring biological diversity. Blackwell Science, Oxford: $256 \mathrm{pp}$.

Mani MS, 1974. Ecology and biogeography in India. W. Junk, The Hague: 647 pp.

Marrone F, Barone R, Naselli Flores L, 2006. Ecological characterization and cladocerans, calanoid copepods and large branchiopods of temporary ponds in a Mediterranean island (Sicily, southern Italy). Chem. Ecol. 22:S181-S190.

Marrone F, Lo Brutto S, Arculeo M, 2010. Molecular evidence for the presence of cryptic evolutionary lineages in the freshwater copepod genus Hemidiaptomus G.O. Sars, 1903 (Calanoida, Diaptomidae). Hydrobiologia 644:115-125.

Marrone F, Lo Brutto S, Hundsdoerfer AK, Arculeo M, 2013. Overlooked cryptic endemism in copepods: systematics and natural history of the calanoid subgenus Occidodiaptomus Borutzky 1991 (Copepoda, Calanoida, Diaptomidae). Mol. Phylog. Evol. 66:190-202.

Marrone F, Petrusek A, Alfonso G, Arculeo M, 2014. The diaptomid fauna of Israel (Copepoda, Calanoida, Diaptomidae), with notes on the systematics of Arctodiaptomus similis (Baird, 1859) and Arctodiaptomus irregularis Dimentman and Por, 1985 stat. rev. Zoological Studies 53:74.

Meshram WJ, 2014. Seasonal Diversity of Copepods in Relation with Physico-Chemical Status of Devtaki Pond, Distt. Gondia, Gondia (M.S.), India. Int. J. Life Sci. A2:147-149.

Mittermeier RA, Gil PR, Hoffman M, Pilgrim J, Brooks T, Mittermeier CG, Lamoreux J, da Fonseca GAB, 2005. Hotspots revisited: Earth's biologically richest and most endangered terrestrial ecoregions. Cemex, Mexico: 392 pp.

Molur S, Smith KG, Daniel BA, Darwall WRT, 2011. The status and distribution of freshwater biodiversity in the Western Ghats, India. Zoo Outreach Organisation: $128 \mathrm{pp}$.

Myers N, Mittermeier RA, Mittermeier CG, da Fonseca GAB, Kent J, 2000. Biodiversity hotspots for conservation priorities. Nature 403:853-858.

Padhye SM, Dahanukar N, 2015. Distribution and assemblages of large branchiopods (Crustacea: Branchiopoda) of northern Western Ghats, India. J. Limnol. 74:371-380.

Padhye SM, Dumont HJ, 2015. Species richness of Cladocera (Crustacea: Branchiopoda) in the Western Ghats of Maharashtra and Goa (India), with biogeographical comments. J. Limnol. 74:182-191.

Pandit SV, Vaidya VV, Joshi PP, 2007. Studies on zooplankton diversity of Pravara river near Sangamner city, dist. Ahmednagar, Maharashtra. J. Aquat. Biol. 22:33-38.

Rajendran M, 1971. Redescription of the freshwater calanoid Neodiaptomus schmackeri and comments on interrelationships and distributional pattern of the schmackeri group of species. Crustaceana 21:92-100.

Ranga Reddy Y, 1988. On the taxonomy of the genus Megadiaptomus Kiefer, including description of a new species (Copepoda, Calanoida) from India. Hydrobiologia 166: 247-262.

Ranga Reddy Y, 1994. Copepoda: Calanoida: Diaptomidae. SPB Publishing. 221 pp.

Ranga Reddy Y, 2013a. Neodiaptomus prateek n. sp., a new freshwater copepod from assam, India, with critical review of generic assignment of Neodiaptomus spp. and a note on diaptomid species richness (Calanoida: Diaptomidae). J. Crustacean Biol. 33:849-865.

Ranga Reddy Y, 2013b. Tropodiaptomus signatus Kiefer 1982, a little known species from Loktak lake, Manipur state, India (Copepoda: Calanoida: Diaptomidae). Crustaceana 86:1675-1688.

Ranga Reddy Y, Radhakrishna Y, 1984. The calanoid and cyclopoid fauna (Crustacea Copepoda) of lake Kolleru, South India. Hydrobiologia 119:27-48.

Rayner NA, 1999. Copepoda: Calanoida: Diaptomidae: Paradiaptominae. Illustrated keys to the genera and species of Paradiaptomus, Lovenula, Neolovenula and Metadiaptomus. Backhyus, Leiden: 122 pp.

Rayner NA, 2000. Distribution and biogeography of the Paradiaptominae (Copepoda: Calanoida: Diaptomidae). Afr. J. Aquat. Sci. 25:93-97.

Reddiah K, 1964. The copepod fauna of Assam (India) 1. Neodiaptomus kamakhiae n. sp. from Kamarup District. Crustaceana 7:161-166.

Schwentner M, Clavier S, Fritsch M, Olesen J, Padhye S, Timms BV, Richter S, 2013. Cyclestheria hislopi (Crustacea: Branchiopoda): a group of morphologically cryptic species with origins in the Cretaceous. Mol. Phylogenet. Evol. 66:800810.

Sehgal K, Phadke GG, Chakraborty SK, Ranga Reddy SVK, 2013. Studies on Zooplankton Diversity in Dimbhe Reservoir, Maharashtra, India. Adv. Appl. Sci. Res. 4:417-420.

Sewell RBS, 1924. Fauna of Chilka lake Crustacea: Copepoda. Mem. Indian Mus. 5:771-851.

Sharma BK, Sharma S, 2007. New records of two interesting chydorid cladocerans (Branchiopoda: Cladocera: Chydoridae) from flood plain lakes of Assam, India. Zoos' Print 22:2799-2801.

Sharma BK, Sharma S, 2014. Faunal diversity of Cladocera (Crustacea: Branchiopoda) in wetlands of Majuli (the largest river island), Assam, northeast India. Opusc. Zool. Budapest 45:1-9.

Shinde YS, Victor R, Pai K, 2014. Freshwater ostracods (Crustacea: Ostracoda) of the plateaus of the northern Western Ghats, India. J. Threatened Taxa 6:5667-5670.

Tavernini S, Fratta E, Sartore F, Rossetti G, 2003. Distribution and ecology of calanoid species in relation to morphometric and chemical characteristics of lakes and ponds in the Northern Apennines (Italy). J. Limnol. 62:28-34. 